\title{
The Differences between Satisfied/Dissatisfied Tourists towards Service Quality and Revisiting Pattaya, Thailand
}

\author{
Surat Supitchayangkool \\ Graduate School of Commerce, Burapha University \\ 169 Longhard Bangsaen Road, A. Muang, Chonburi 20131, Thailand \\ E-mail: suratsme@gmail.com
}

Received: November 20, 2011

Accepted: January 31, 2012

Published: March 16, 2012

doi:10.5539/ijbm.v7n6p30

URL: http://dx.doi.org/10.5539/ijbm.v7n6p30

\begin{abstract}
This research aims to study the relationship between service quality and tourists' intention to revisit Pattaya, one of the most famous tourist destinations in Thailand, and to compare the difference in opinions of satisfied and dissatisfied tourists toward the service quality provided by Pattaya. A questionnaire was used to survey 400 American and European tourists who were selected by convenience sampling method. The results show that 307 tourists were satisfied $(76.75 \%)$ while 93 tourists were dissatisfied $(23.25 \%)$ with the service quality of Pattaya. Of the 307 satisfied tourists, 264 were Europeans (86\%) and 43 were Americans (14\%), while the dissatisfied 93 tourists consisted of 85 Europeans (91.4\%) and 8 Americans (8.6\%). For the satisfied tourists, the overall service quality had a positive relationship with the intention to revisit. Elements of service quality which had a positive relationship with the intention to revisit were core-tourism experience, information, hospitality, fairness of price, value for money, logistics, and food. For the dissatisfied tourists, the overall service quality had a positive relationship with the intention to revisit. Elements of service quality which had a positive relationship with the intention to revisit were core-tourism experience, information, hospitality, fairness of price, hygiene, value for money, and logistics. Compared with the dissatisfied tourists, satisfied tourists showed a significantly higher perception towards the service quality of Pattaya.
\end{abstract}

Keywords: Tourist satisfaction, Intention to revisit, Thailand

\section{Introduction}

In marketing literature, there are several research studies about the relationship between satisfaction and repurchase or post-purchase satisfaction judgment (Bou-Llusar, Camison-Zornoza, Escrig-Tena, 2001). For customers satisfied with goods or experiences, the satisfaction situation reflects an inherent positive relationship between satisfaction and intention to repurchase (Mullin, Hardy, and Sutton, 2000).

The concept of satisfaction is not only studied in the goods industry but is also studied in the recreation industry, where the satisfaction in recreation industry links to the service quality provided by organizations or places to visit. Hui, Wan and Ho (2007) found that tourists were willing to recommend Singapore to their friends and relatives when they were satisfied with the place they visited and also they were willing to revisit Singapore in the future.

In the tourism industry, the study about service quality, customer satisfaction and intention to revisit are important elements for developing marketing strategies about how tourism products are designed to satisfy the needs of target market (Jayawardena, 2002). The results can identify and exploit new opportunities that are attractive, economical, rewarding and sustainable for the destinations (Buhalis, 2000).

Pattaya is one of the most famous tourist destinations in Thailand and perhaps in South-east Asia. Pattaya is in Chonburi Province which is located in the eastern part of Thailand. Pattaya, located off the Gulf of Thailand, and is approximately $145 \mathrm{~km}$ south of the city of Bangkok. It is divided into a larger northern section, which spans the areas to the east of Naklua Beach (the northern beach) and Pattaya Beach (the main beach) plus the Pratamnak Hill or Buddha Hill, headland (the south of Pattaya Beach), and a smaller southern section covering the area to the east of Jomtien Beach (Wikipedia, 2011).

Numerous tourists, both Thai and foreign visit Pattaya every year. In 2010, there were 5,359,669 foreign tourists who visited Pattaya, while for the year 2009 there were 2,716,938 tourists. Hence, there was a $97.27 \%$ increase 
from the year 2009 to 2010 (Office of Tourism Development, 2011). The average length of stay in the year 2010 was 3.5 days, the average expenditure was 3,253.56 Baht per person per day, and the revenue that derived from tourists was 60,374.58 million baht (Department of Tourism, 2011).

Therefore, this study intends to examine the relationship between service quality of travel destination and return to visit by comparing perception of both satisfied and dissatisfied tourists at Pattaya Thailand. The benefits of this study can be to provide a greater understanding about the service quality that a travel destination should provide in order to increase more intentions to revisit.

\section{Literature Review}

\subsection{Service Quality}

The quality of service involved with tourism plays an important role in the process of delivery (Wyllie, 2000), and can be the standard for assessing the effectiveness of a particular tourism service sector (Godbey, 1997: cited in Alvin Hung-Chih, Duarte, \& Garry, 2005).

In the year 2002, Sureshchandar, Rajendran, and Anatharaman reviewed the SERVQUAL scale and found that all items only dealt with the human element of human interaction in service delivery, while it overlooked some other important factors of service quality such as core service, systematization/standardization of service delivery, and social responsibility of the service organization.

For the tourism industry, the quality of tourism product is defined as "The sum of contributions and processes, resulting from many stakeholders, both private and public. The notion of quality of the tourism product includes assurance of safety and security as a basic factor. Quality also includes a professional approach to do things right at all times and meet legitimate expectations of consumers (Narayan, Rajendran, \& Sai, 2008, p. 470).

There were several researches which studied the measurement of service quality in tourism. Eraqi (2006) studied tourism service quality in Egypt by collecting data both form external and internal customers, he found that the factors that measured hotel service quality were: service prices, level of services at accommodations, and internal transport quality. Poon and Low (2005) examined the factors which measured customer satisfaction between the Asian and Western travelers during their stay in hotels in Malaysia by using: hospitality, accommodation, food and beverages, recreation and entertainment, supplementary services, security and safety, innovation and value-added services, transportation, location, appearance, pricing and payment. Millan and Esteban (2004) measured service quality for travel agencies by using six dimensions: service encounters, empathy, reliability, service environment, efficiency of advice and additional attributes.

This research used the service quality for tourism scale that was developed by Narayan, Rajendran, and Sai (2008), whereby they conducted research by using the second-order factor analysis as research methodology to analyze the data that they collected from tourist-destination in India called Kerala which is one of the 50 destinations in the world that must be seen during one's lifetime. They collected data from 412 tourists by convenience sampling during January 2006-May 2006 and 396 tourists who willingly filled out the questionnaire. The development of a scale to measure and benchmark service quality in tourism consisted of ten dimensions:

1) Core-tourism experience: the primary item that tourists want to get consists of; natural beauty, good climate, richness of cultural heritage, scope for cultural exchange with local people, closeness to nature, sightseeing, variety of landmarks, privacy and an ambience enabling a relaxed leisure time.

2) Information: information required by tourists including information about destination available at the airport, places to stay, tourist spots, tour guide service or a voice-over, and ease of communicating in a common language with local people. But for this study, data was collected from tourists who visited Pattaya by themselves, not utilizing the availability of information at the airport or from tour guides.

3) Hospitality: the courteousness, friendliness, trustworthiness, and reliability of hotel staff and local people. Nevertheless, the study of Narayan, Rajendran, and Sai (2008) also included hospitality of immigration officials at the port of entry and tour operator.

4) Fairness of price: the fairness of products' cost at tourist spots and shops as well as local conveyances.

5) Hygiene: the cleanliness and hygiene of a place to stay, tourist spots and restaurants, streets, and food. In the study of Narayan, Rajendran, and Sai (2008) the hygiene of the airport was also included.

6) Amenities: the availability of internet, telecommunication services and money exchange facilities.

7) Value for money: the value for money with respect to the tour package, accommodation, domestic flight, food at restaurants, local conveyance, and also at shopping spots. But for this study the value for money focused 
on food at restaurant, accommodation, and shopping spots.

8) Logistics: the accessibility of tourist spots as well as conditions of infrastructure.

9) Food: The taste of local food and availability of food.

10) Security: free from terrorist attacks or feeling safe at the hotel and tourist spots.

\subsection{The Relationship between Satisfaction and Intention to Revisit}

The causal relationship of satisfaction and revisit is one of interest to study in the context of tourism. Qing Chi and $\mathrm{Qu}$ (2008) found the overall satisfaction and attribute satisfaction had direct and positive impact on destination loyalty. Yuskel (2000) noted the relationship between satisfaction and repeat business for various travel destinations. Some studies found that travelers with prior experience of a destination have greater satisfaction levels than those who have no prior experience (Kozak \& Rimmington, 2000). Then satisfaction from a past experience was positively related to satisfaction with the current visit to the same destination, and then feelings of satisfaction in the current visit affect the behavior towards a revisit.

Nevertheless, the intention to repurchase or return to visit may not relate to satisfaction. In airlines, banks or multiple product categories, Anderson and Sullivan (1990) stated that negative perceptions had greater affects on intention to repurchase than positive perceptions. Mittal, Ross and Baldasare (1998) found that negative satisfaction had a greater affect on repurchase intentions than positive satisfaction.

\subsection{The Relationship among Service Quality, Customer Satisfaction, and Intention to Revisit}

Lee, Lee, and Wicks (2004) investigated the relationship between service quality and satisfaction and their influences on behavioral intentions among foreign visitors. They found that service quality proved to be an antecedent of satisfaction, and satisfaction played a partial mediating role between service quality and behavioral intention. Baloglu, et al. (2003) examined the relationships among destination performance, overall satisfaction, and behavioral intention of various market segments among Canadian visitors to Las Vegas. They found that overall satisfaction played a mediating role between destination performance and behavioral intention, both at the individual segment level and at the aggregate sample level. Nevertheless, they did not find a direct relationship between destination performance and behavioral intention. While Cole and Scott (2004) studied the mediating role of experience quality between performance quality and overall satisfaction, the results showed that experience quality fully mediated the relationship between performance quality and overall satisfaction, while overall satisfaction in turn had a significant effect on revisit intention.

\section{Methodology}

This study was a descriptive research using a questionnaire as the method for collecting data at Pattaya, Thailand. By calculating Yamane's sampling formula (1967), there were 430 American and European tourists who could understand English who were invited to fill out the questionnaire by using a systematic sampling collecting sample in North Pattaya, Central Pattaya, South Pattaya, and Jomthien beach. The reason why the collected data referred only to American and European tourists was because, regardless of Asian tourists, the tourists from both these regions were of a majority than the number of tourists from Oceania, Middle-East and Africa. The respondents were selected by convenience sampling. The completed total of returned questionnaires was 400 questionnaires which could be used for data analysis.

The questionnaire consisted of 4 parts:

The first part is personal information using nominal and ordinal scales inquiring about tourists' nationality whether they were European or American, gender, marital status, age, level of education, occupation, number of people in group, and if they had visited Pattaya before.

The second part is a set of questions about tourists' perception toward service quality of destination using 10 items adapted from Narayan, Rajendran, and Sai (2008): core-tourism experience, information, hospitality, fairness of price, hygiene, amenities, value of money, logistics, food, and security. The respondents were asked to respond to the statement indicating the level of perception toward service quality of each indicator measured on a five-point Likert scale (1-low to 5-high).

The third part is questioning regarding tourists' satisfaction, which contained only one item to measure the whole satisfaction they got from travelling to Pattaya. The respondents were asked to respond to a statement indicating the level of satisfaction on a five-point Likert scale (1-low to 5-high). The reliability analysis is demonstrated in Table 1. 
The forth part is questioning regarding intention to revisit using only one item "If you plan to travel, Pattaya is the first choice to revisit". The respondents were asked to respond to the statement indicating the level of revisit on a five-point Likert scale (1-low to 5-high).

First of all, the level of tourists' satisfaction was classified into two groups: satisfied and dissatisfied tourists by examining the average mean of each person. If the level of satisfaction was equal to or above 3.51 then they were satisfied people, on the other hand if the level of satisfaction was less than 3.50 then they were dissatisfied people. Then the data was analyzed using descriptive statistics consisting of frequency and percentage, while inferential statistics were used to solve hypothesis one with the Pearson correlation and hypothesis two with the independent sample t Test.

\section{Results}

This study found that from 400 respondents, there were 307 tourists who were satisfied with the service quality $(76.75 \%)$ and 93 tourists who were dissatisfied (23.25\%). Of the 307 satisfied tourists, there were 264 Europeans (86\%) and 43 Americans (14\%), while of the 93 tourists who were dissatisfied there were 85 Europeans (91.4) and 8 Americans $(8.6 \%)$.

Of the 307 satisfied tourists, there were 109 tourists (35.51\%) who were not revisiting and 198 tourists $(64.49 \%)$ who were revisiting. Whereas of the 93 dissatisfied tourists, there were 64 tourists $(68.82 \%)$ who were not revisiting and 29 tourists (31.18\%) who were revisiting.

\section{Insert Table 2- here}

Testing hypothesis 1 : There is a positive relationship between service quality and intention to revisit of satisfied tourists.

The results showed that for the satisfied tourists, the overall service quality has a positive relationship with the intention to revisit $(\mathrm{r}=0.326$, $\mathrm{p}$-value $<0.05)$. Elements of service quality which have a positive relationship with revisiting are; core-tourism experience, information, hospitality, fairness of price, value for money, logistics, and food.

Testing hypothesis 2 : There is positive relationship between service quality and intention to revisit by dissatisfied tourists.

The results showed that for the dissatisfied tourist, the overall service quality has a positive relationship with the intention to revisit $(\mathrm{r}=0.436$, $\mathrm{p}$-value $<0.05)$. Elements of service quality which have a positive relationship with revisiting are; core-tourism experience, information, hospitality, fairness of price, hygiene, value for money, and logistics.

\section{Insert Table 3- here}

Testing hypothesis 3 : There is a significant difference of opinion toward service quality provided by a travel destination between satisfied and dissatisfied tourists.

The results showed that there is a significant difference of opinion toward service quality provided by a travel destination between satisfied and dissatisfied tourists. The satisfied tourists had a higher means of opinion toward service quality than the dissatisfied tourists ( $\mathrm{p}$-value $<0.05$ ).

\section{Insert Table 4- here}

\section{Discussion}

As Pattaya is a famous place which many tourists wanted to visit once in their life, there was higher number of satisfied tourists than dissatisfied tourists and a higher number of tourists who visited Pattaya before than tourists who had just visited for the first time. The results showed that $64.49 \%$ of satisfied tourists will come back to Pattaya again and $31.18 \%$ of unsatisfied tourists will revisit. From the study of Alegre and Cladera (2007), they stated that the main factors which determined an intention to revisit seemed to be; tourist satisfaction with their stay, specific motivation in choosing a destination and tourist attachment to it. Thus tourist satisfaction with a destination has become a key indicator for regional tourist industries (Kozak, 2001). Hence, it is necessary to explain tourist satisfaction with a destination based on tourists' perceptions of different service quality aspects provided by the destination.

According to hypothesis one and two, the overall service quality had a positive relationship with revisits of both satisfied and dissatisfied tourists. The reason behind their opinions may be a consequence of routine behavior (Oppermann, 2000). By examining each element of service quality indicators; core-tourism experience had a positive relationship with the intention to revisit by both satisfied and dissatisfied tourists. Crick-Furman and 
Prentice (2000) stated that successful promotion of destination's positioning strategy requires accommodating tourists in comfortable environments, where the tourists preferred to visit cultural and historic places of interest.

Information had a positive relationship with the intention to revisit by both satisfied and dissatisfied tourists. Information search was the motivating activation of knowledge stored in memory (Gursoy and McClearly, 2004). Marketing destination managers should try to influence the consumers by providing information that fits in with the consumer search process where core elements can be brochures, website information and advertising material such as print, TV, radio, outdoor (Bronner and Hoog, 2007). Fodness and Murray (1999) stated that tourist behavior was attributed to the information available to them. During information acquisition, marketers can influence consumers' buying decisions (Gursoy and McCleary, 2004).

Hospitality had a positive relationship with the intention to revisit by both satisfied and dissatisfied tourists. As O'Leary and Deegan (2005) indicated that welcome and friendly hotel staff, tourist spots' staff, and local people were indicators to measure quality of place. In addition, Chaniotakis and Lymperopoulos (2009) found that empathy, responsiveness, assurance of service providers had an indirect effect of word-of-mouth communication through satisfaction.

Fairness of price had a positive relationship with the intention to revisit by both satisfied and dissatisfied tourists. According to Alegre and Cladera (2007), motivation by price had a negative relationship with the intention to revisit. This means if there is a higher price of products or service at a destination, it may affect tourists' intention to return. The destination should provide a fairness of price to encourage tourists to come back.

Hygiene had no relationship with the intention to revisit by satisfied tourists but had positive relationship with dissatisfied tourists. Hence Pattaya should beware of places and tourists' spots which should be clean enough. Thailand is a developing country and when compared to America or Europe the hygiene of places may be at a lower standard. Moreover, Yuksel and Yuksel (2001) confirmed that with a travel destination such as India the unpleasant atmosphere created by beggars and hawkers would also be a reflection of the hygiene of the place.

Amenities had no relationship with the intention to revisit by both satisfied and dissatisfied tourists. Apart from the nightlife amenities, Pattaya should provide enough telecommunication services, money exchange spots, and internet access shops.

Value for money had a positive relationship with the intention to revisit by satisfied tourists but had no relationship with dissatisfied tourists. Supporting the results of this study, Lee, Lee, and Lee, 2005) also found that there was a relationship between destination quality and value perceived by tourists during their visit. Wilensky and Buttle (1988) supported that; physical attractiveness, opportunities for relaxation, standard of services and appealing image were factors that travelers considered when they evaluated value for money.

Logistics had a positive relationship with the intention to revisit by both satisfied and dissatisfied tourists. The tourists determined that the convenience of accessibility to tourists' spots as an indicator for their revisit to Pattaya because there was plenty of transportation provided in Pattaya. There were no traffic jams in Pattaya as well. Logistics or local transport services should be served with a reasonable price, frequency, variety of access to attractions, and comfortablity (Kozak, 2001).

Food had a positive relationship with the intention to revisit by satisfied tourists, but had no relationship with dissatisfied tourists. Food is an important tourist attraction and enhances visitors' experience (Henderson, 2009). Food offers pleasure and entertainment to tourists, helping tourists to understand different eating behavior and culture between their own and those with which they come to visit (Hegarty and O'Mahoney, 2001). A country's food can be shown as a destination image to advertise. The most famous Thai dishes were "Tom Yam Krung", "Papaya Salad", "Red Curry", and "Green Curry".

Security had no relationship with the intention to revisit by both satisfied and dissatisfied tourists. For both satisfied and dissatisfied tourists recognized that there were plenty of tourists who visited Pattaya every year. Security of the place had not affected them when determining to revisit. However, Mawby (2000) proposed that tourists should be informed of the risks of visiting tourist areas in order to decrease nervousness of criminal behavior.

In conclusion, according to the study of Oh and Park (1997), Oh (1999), Yuskel (2000), Kozak and Rimmington (2000), and Beaman, Kozak, and Huan (2001; cited in Bo Ho (2003)) the satisfaction of tourists had a positive relationship with a return to visit. Moreover, the service quality also had a relationship with revisiting. From the results of this study, the components of service quality that encouraged both satisfied and dissatisfied tourists to revisit were; core-tourism experience, information, hospitality, fairness of price, value for money and logistics, while food was a component that can encourage satisfied tourist to revisit and hygiene was a component that can 
encourage dissatisfied tourist to revisit. Examining the relationship (r), the relationship between service quality components and intention to revisit of dissatisfied tourists was higher than satisfied tourists except value for money.

According to hypothesis three, the satisfied and dissatisfied tourists had a difference of perception toward service quality. Tourists who were satisfied with travelling perceived the service quality derived from a destination more so than the tourists who were not satisfied. The mean of the service quality for each component under the perception of satisfied tourists was at a moderate to high level (2.51-4.50). Whereas the mean of the service quality for each component under the perception of dissatisfied tourists was at a moderate level (2.51-3.50), except for hospitality and food. For both satisfied and dissatisfied tourists food had the highest mean, while hygiene had the lowest mean.

\section{Conclusion}

\subsection{Conclusions and recommendation}

Pattaya was a good place to visit for tourists especially for the tourists from America and European countries. The majority of tourists was satisfied with the service quality of the travel destination and was willing to come back again. Service quality was one of the key success factors that can encourage tourists to feel satisfied and revisit especially if Pattaya provided a high service quality in order to retain the tourists especially focusing on improving; core-tourism experience, information, hospitality, fairness of price, value for money and logistics which had a positive relationship with intention to revisit of both satisfied and dissatisfied tourists.

Pattaya is a dominant tourist destination. Beside the reputation of Pattaya regarding beach activities, nightlife and other activities, the destination managers should emphasize providing good service quality to satisfy the needs of tourists in order to increase revisits. In order to capture the American and European markets, the policy makers need to have cooperation from the stakeholders. The tourists examined price and value for money, thus setting prices for hospitality, food, and related activities should be reasonable. Alternative facilities and fresh food should be provided, as well as transportation, also security and safety must be factors of concern. Hotel managers and managers at tourist spots have to devote extra effort into developing the workers to have higher serving skills, upgrading quality standards, value added service, and make employees realize that a warm and cordial reception is imperative in their professional make-up.

\subsection{Recommendations for Further Study}

6.2.1 Researchers should examine in-depth details for each item and also examine other factors of service quality.

6.2.2 Researchers should study other tourist nationalities as tourists who visit Pattaya are not only European or American, but there are also Asian tourists such as Chinese, Koreans, Japanese, Taiwanese for example.

6.2.3 As Thailand has many places for travelling to such as Phukhet, Samui Island, and other places in the North of Thailand for example, researchers should investigate factors in those areas that can be key success factors for tourism in order to make tourists feel impressed and want to come back.

\section{Limitation of the Study}

As the data focused on one destination such as Pattaya, it might be considered a delimitation by some and that this knowledge may not be directly generalized to all domestic destinations throughout Thailand or for the tourists who have different culture or nations.

\section{References}

Alegre, J., \& Cladera, M. (2009). Analysing the effect of satisfaction and previous visits on tourist intentions to return. European Journal of Marketing, 43(5/6), 670-685. http://dx.doi.org/10.1108/03090560910946990

Alvin Hung-Chih., Duarte, M., \& Garry, C. (2005). Service quality in tourism: A case study of the 2001 study tour of Taiwan. In proceeding of the 2005 Northeastern Recreation Research Symposium, 318-325.

Anderson, E. W., \& Sullivan, W. M. (1990). The antecedents and consequences of customer satisfaction for firms. Marketing Science, 12(2), 125-143. http://dx.doi.org/10.1287/mksc.12.2.125

Baloglu, S., Pekcan, A., Chen, S. L., \& Santos, J. (2003). The relationship between destination performance, overall satisfaction, and behavioral intention for distinct segment. Journal of Quality Assurance in Hospitality and Tourism, 4(3/4), 149-165. http://dx.doi.org/10.1300/J162v04n03_10

Bou-Llusar, J. C., Camison-Zornoza, C., \& Escrig-Tena, A. B. (2001). Measuring the relationship between firm perceived quality and customer satisfaction and its influence on purchase intentions. Total Quality 
Mananagement, 12(6), 719-734. http://dx.doi.org/10.1080/09544120120075334

Bronner, F., \& Hoog R. (2007). A new perspective on tourist information search: discussion in couples as the context. International Journal of Culture, Tourism and Hospitality Research, 5(2), 128-143. http://dx.doi.org/10.1108/17506181111139555

Buhalis, D. (2000). Marketing the competitive destination of the future. Tourism Management, 21, 97-116. http://dx.doi.org/10.1016/S0261-5177(99)00095-3

Chaniotakis, I. E., \& Lymperpoulos, C. (2009). Service quality effect on satisfaction and word of mouth in the health care industry. Managing Service Quality, 19(2), 229-242. http://dx.doi.org/10.1108/09604520910943206

Cole, S., \& Scott, D. (2004). Examining the mediating role of experience quality in a model of tourist experiences. Journal of Travel and Tourism Marketing, 16(1), 77-88. http://dx.doi.org/10.1300/J073v16n01_08

Crick-Furman, D., \& Prentice, R. (2000). Modeling tourists' multiple values. Annuals of Tourism Research, 27(1), 69-92. http://dx.doi.org/10.1016/S0160-7383(99)00041-9

Department of Tourism. (2010). Tourists arrival in Thailand. [Online] Available: http://www.tourism.go.th/2010/upload/filecenter/file/stat_2553/Update\%20on\%203Aug\%2054/East.pdf (August $18,2011)$

Eraqi, M. I. (2006). Tourism service quality (TourServQual) in Egypt. The viewpoint of external and internal customers. Benchmarking: An International Journal, 13(4), 469-492. http://dx.doi.org/10.1108/14635770610676308

Fodness, D., \& Murray, B. (1999). A model of tourist information search behavior. Journal of Travel Research, 37, 220-230. http://dx.doi.org/10.1177/004728759903700302

Gursoy, D., \& McCleary, K. W. (2004). An integrative model of tourists' information search behavior. Annual of Tourism Research, 31(2), 353-373. http://dx.doi.org/10.1016/j.annals.2003.12.004

Hagarty, J. A., \& O’Mahoney, G. B. (2001). Gastronomy: a phenomenon of cultural expressionism and an aesthetic for living. International Journal of Hospitality Management, 20(1), 3-13. http://dx.doi.org/10.1016/S0278-4319(00)00028-1

Henderson, J. C. (2009). Food tourism reviewed. British Food Journal, 111(4), 317-326. http://dx.doi.org/10.1108/00070700910951470

Hui K. T., Wan, D., \& Ho A. (2007). Tourists' satisfaction, recommendation and revisiting Singapore. Tourism Management, 28, 965-975. http://dx.doi.org/10.1016/j.tourman.2006.08.008

Jayawardena, C. (2002). Mastering Caribbean tourism. International Journal of Contemporary Hospitality Management, 24(2), 88-93. http://dx.doi.org/10.1108/09596110210419273

Kozak, M. (2001). Comparative assessment of tourist satisfaction with destinations across two nationalities. Tourism Management, 22, 391-401. http://dx.doi.org/10.1016/S0261-5177(00)00064-9

Kozak, M. (2001). Repeaters' behavior at two distinct destinations. Annuals of Tourism Research, 28(3), 784-807. http://dx.doi.org/10.1016/S0160-7383(00)00078-5

Kozak, M., \& Rimmington, M. (2000). Tourist satisfaction with Mallorca, Spain, as an off-season holiday destination. Journal of Travel Research, 39(3), 260-269. http://dx.doi.org/10.1177/004728750003800308

Lee, C. J., Lee, Y. K., \& Wicks, B. E. (2004). Segmentation of festival motivation by nationality and satisfaction. Tourism Management, 25(1), 51-70. http://dx.doi.org/10.1016/S0261-5177(03)00060-8

Lee, C., Lee, Y., \& Lee, B. (2005). Korea's destination image formed by the 2002 World Cup. Annuals of Tourism Research, 32(4), 839-585. http://dx.doi.org/10.1016/j.tourman.2004.03.002

Mawby, R. I. (2000). Tourists' perception of security: the risk-fear paradox. Tourism Economics, 6(2), 109-121. http://dx.doi.org/10.5367/000000000101297514

Millan, A., \& Esteban, A. (2004). Development of a multiple-item scale for measuring customer satisfaction in travel agencies services. Tourism Management, 25(5), 533-546. http://dx.doi.org/10.1016/j.tourman.2003.07.002

Mittal, V. W. T., Ross, Jr., \& Bladasare, M. P. (1998). The asymmetric impact of negative and positive attribute-level performance on overall satisfaction and repurchase intentions. Journal of Marketing, 62(1), 33-47. http://dx.doi.org/10.2307/1251801

Mullin, B. J., Hardy, S., \& Sutton, W. A. (2000). Sport marketing (2nd ed.). Champaign, IL: Human Kinetics. 
Narayan B., Rajendran, C., \& Sai, P. (2008). Scales to measure and benchmark service quality in tourism industry: A second-order factor approach. Benchmarking: An International Journal, 15(4), 469-493. http://dx.doi.org/10.1108/14635770810887258

O'Leary, S., \& Deegan, J. (2005). Ireland's image as a tourism destination in France: attribute important and performance. Journal of Travel Research, 43, 247. http://dx.doi.org/10.1177/0047287504272025

Oppermann, M. (2000). Where psychology and geography interface in tourism research an theory, in Woodside, A. G., Grouch, G. I., Mazanec, J. A., Oppermann, M., \& Sakai, M.Y. (Eds.), Consumer Psychology of Tourism, Hospitality and Leisure (pp. 9-38). Wallingford: CABI Publishing. http://dx.doi.org/10.3727/108354206778689835

Poon, W., \& Low, K. (2005). Are travelers satisfied with Malaysian hotels?. International Journal of Contemporary Hospitality Management, 17(3), 217-227. http://dx.doi.org/10.1108/09596110510591909

Qing Chi, C, G., \& Qu, H. (2008). Examining the structural relationships of destination image, tourist satisfaction and destination loyalty: an integrated approach. Tourism Management, 29(4), 624-636. http://dx.doi.org/10.1016/j.tourman.2007.06.007

Sureshchandar, G. S., Rajendran, C., \& Kamalanabhan, T. J. (2002). The relationship between service quality and customer satisfaction- a factor specific approach. Journal of Service Marketing, 16(4), 363-379. http://dx.doi.org/10.1108/08876040210433248

Wikipedia. (2011). Information about Pattaya. [Online] Available: http://en.wikipedia.org/wiki/Pattaya\#Physical_geography (August 18, 2011)

Wilensky, L., \& Buttle, F. (1988). A multivariate analysis of hotel benefit bundles and choice trade-offs. International journal of Hospitality Management, 7(1), 29-41. http://dx.doi.org/10.1016/0278-4319(88)90008-4 Wyllie, R. W. (2000). Tourism and Society. State College, PA: Venture Publishing.

Yamane, T. (1967). Elementary Sampling Theory. USA: Prentice Hall.

Table 1. Reliability analysis

\begin{tabular}{|l|c|}
\hline \multicolumn{1}{|c|}{ Service quality } & Cronbach alpha \\
\hline Core-tourism experience & 0.742 \\
\hline Information & 0.751 \\
\hline Hospitality & 0.733 \\
\hline Fairness of price & 0.816 \\
\hline Hygiene & 0.811 \\
\hline Amenities & 0.842 \\
\hline Value for money & 0.844 \\
\hline Logistics & 0.714 \\
\hline Food & 0.713 \\
\hline Security & 0.787 \\
\hline
\end{tabular}

Remark: 35 respondents were selected to try-out the questionnaires 
Table 2. Personal data of respondents

\begin{tabular}{|c|c|c|c|}
\hline \multicolumn{2}{|c|}{ Personal Data } & Amount (No. & Percentage \\
\hline Nationality & $\begin{array}{l}\text { European } \\
\text { American }\end{array}$ & $\begin{array}{r}349 \\
51 \\
\end{array}$ & $\begin{array}{l}87.2 \% \\
13.8 \% \\
\end{array}$ \\
\hline Gender & $\begin{array}{l}\text { Male } \\
\text { Female }\end{array}$ & $\begin{array}{l}296 \\
104 \\
\end{array}$ & $\begin{array}{l}74.0 \% \\
26.0 \% \\
\end{array}$ \\
\hline Marital status & $\begin{array}{l}\text { Single } \\
\text { Married } \\
\text { Divorced/Separated } \\
\end{array}$ & $\begin{array}{r}221 \\
132 \\
47 \\
\end{array}$ & $\begin{array}{l}55.3 \% \\
33.0 \% \\
11.7 \% \\
\end{array}$ \\
\hline Age & $\begin{array}{l}\text { Under } 25 \text { years old } \\
25-34 \text { years old } \\
35-44 \text { years old } \\
45-54 \text { years old } \\
55 \text { years old and over }\end{array}$ & $\begin{array}{l}55 \\
88 \\
88 \\
80 \\
89 \\
\end{array}$ & $\begin{array}{l}13.8 \% \\
22.0 \% \\
22.0 \% \\
20.0 \% \\
22.2 \% \\
\end{array}$ \\
\hline Level of education & $\begin{array}{l}\text { Lower than bachelor degree } \\
\text { Bachelor degree } \\
\text { Higher than bachelor degree } \\
\text { Others }\end{array}$ & $\begin{array}{r}86 \\
229 \\
77 \\
8 \\
\end{array}$ & $\begin{array}{r}21.5 \% \\
57.3 \% \\
19.3 \% \\
1.9 \%\end{array}$ \\
\hline Occupation & $\begin{array}{l}\text { Governmental organization } \\
\text { employee } \\
\text { Private organization employee } \\
\text { Business owner } \\
\text { Students } \\
\text { Others }\end{array}$ & $\begin{array}{r}69 \\
140 \\
113 \\
29 \\
49 \\
\end{array}$ & $\begin{array}{r}17.25 \% \\
35.0 \% \\
28.25 \% \\
7.25 \% \\
12.25 \% \\
\end{array}$ \\
\hline Number of people in group & $\begin{array}{l}1-2 \text { persons } \\
3-4 \text { persons } \\
5-6 \text { persons }\end{array}$ & $\begin{array}{r}293 \\
79 \\
28 \\
\end{array}$ & $\begin{array}{r}73.25 \% \\
19.75 \% \\
7.0 \% \\
\end{array}$ \\
\hline Visit Pattaya before & $\begin{array}{l}\text { Yes } \\
\text { No }\end{array}$ & $\begin{array}{l}262 \\
138 \\
\end{array}$ & $\begin{array}{l}65.5 \% \\
34.5 \% \\
\end{array}$ \\
\hline
\end{tabular}

Table 3. Shows the relationship between service quality and intention to revisit of satisfied and dissatisfied tourists

\begin{tabular}{|l|c|c|}
\hline \multicolumn{1}{|c|}{ Service Quality/Revisit } & Satisfaction & Dissatisfaction \\
\hline Core-tourism experience & $0.199^{*}$ & $0.387^{*}$ \\
\hline Information & $0.210^{*}$ & $0.344^{*}$ \\
\hline Hospitality & $0.262^{*}$ & $0.381^{*}$ \\
\hline Fairness of price & $0.252^{*}$ & $0.294^{*}$ \\
\hline Hygiene & 0.098 & 0.183 \\
\hline Amenities & 0.226 & $0.226^{*}$ \\
\hline Value for money & $0.261^{*}$ & $0.317^{*}$ \\
\hline Logistics & $0.164^{*}$ & 0.195 \\
\hline Food & $0.205^{*}$ & 0.116 \\
\hline Security & 0.051 & $0.436^{*}$ \\
\hline Overall service quality & $0.326^{*}$ & \\
\hline
\end{tabular}

*p-value $<0.05$ 
Table 4. Shows a significant difference of perception toward service quality provided by a travel destination between satisfied and dissatisfied tourists.

\begin{tabular}{|ll|c|c|}
\hline \multicolumn{2}{|c|}{ Service Quality } & Satisfaction (mean) & dissatisfaction (mean) \\
\hline Core-tourism experience & $\mathrm{t}=-6.97^{*}$ & 3.76 & 3.21 \\
\hline Information & $\mathrm{t}=-3.46^{*}$ & 3.82 & 3.49 \\
\hline Hospitality & $\mathrm{t}=-4.25^{*}$ & 3.99 & 3.58 \\
\hline Fairness of price & $\mathrm{t}=-4.46^{*}$ & 3.26 & 3.71 \\
\hline Hygiene & $\mathrm{t}=-5.76^{*}$ & 3.19 & 2.60 \\
\hline Amenities & $\mathrm{t}=-7.05^{*}$ & 3.55 & 2.95 \\
\hline Value for money & $\mathrm{t}=-6.11^{*}$ & 3.80 & 3.21 \\
\hline Logistics & $\mathrm{t}=-6.61^{*}$ & 3.67 & 3.10 \\
\hline Food & $\mathrm{t}=-6.48^{*}$ & 4.24 & 3.59 \\
\hline Security & $\mathrm{t}=-5.42^{*}$ & 3.60 & 3.01 \\
\hline Overall service quality & $\mathrm{t}=-6.63^{*}$ & 3.69 & 3.08 \\
\hline
\end{tabular}

*p-value $<0.05$ 